\title{
Training Needs Assessment on the Use of Social Media among Extension Agents in Oyo State, Nigeria
}

\author{
Kehinde Adesina Thomas ${ }^{1}$ Ayobami Abiola Laseinde ${ }^{2}$
}

\begin{abstract}
I N F O
Received 31 June 2014

Accepted 29 Dec 2014

Available on-line 14 Jan 2015

Responsible Editor: M. Herdon

Keywords:

Social Media, Training Needs, ICT, Agricultural Extension

A B S T R A C T

Agricultural information exchange has been dominated by industrial media such as newspapers, television, and magazines for decades. However, social media as a form of Information and Communication Technology (ICT) method for harmonizing sustainable agriculture and natural resources provides broader agricultural community that eliminates physical distance. The study therefore examined training needs assessment on the use of social media among agricultural extension agents in Oyo State, Nigeria. All the 90 agricultural extension agents in Oyo State Agricultural Development Programme (OYSADEP) were interviewed. This includes 35 from Ibadan|Ibarapa zone, 22 from Saki, 19 from Oyo and 14 from Ogbomosho zone. Result shows that the mean age of extension agents in Oyo State was $38 \pm 2$ years, $(98.8 \%)$ had one form of tertiary education or the other. Majority (72.0\%) exhibited high need for training on the use of social media even when the result revealed that Facebook $(47.6 \%)$ was mostly used social media among the agents. The result of inferential statistics shows that there was a significant relationship between education $\left.\chi^{2}=10.142, \mathrm{p}<0.05\right)$, marital status $(\chi 2=19.632, \mathrm{p}<0.05)$, social media used $(r=-0.337, p<0.05)$ and training needs. However, inverse but significant relationship existed between extension agents' knowledge of social media $(r=-0.875, p<0.05)$ and training needs. Concerted efforts by relevant stakeholders to train extension agents will in no measure foster sustainable food security drive in Nigeria.
\end{abstract}

\section{Introduction}

Increasing smallholder productivity is one the greatest challenge in this century. The dimensions of the challenge include growing populations, growing demand for food, rising poverty, economic stagnation, worsening environmental degradation, and climate change. ICTs based applications like Variable rate technology, Geographical Information System (GIS), Geographical Position System (GPS), satellite imagery, and other data collection technologies have increased the information available about soil health, weather conditions, and disease outbreaks. These ICTs based applications provide information that makes very site-specific farming possible and thereby raising hope for agricultural productivity. However, the key to using these technologies to boost productivity requires complementary technologies. Data analysis technologies (such as data mining or mediation software) and information dissemination technologies (such as mobile phones and radio) are essential to reaching smallholders effectively. Dissemination also includes the crucial human component: Extension agents and farmers themselves must transmit and share knowledge (International Institute for Communication and Development (IICD), 2006).

Agricultural enterprise requires knowledge management to enhance agricultural productivity and combat the problem of food insecurity. This enables appropriate agricultural information to reach agricultural extension agents (knowledge intermediaries) and smallholder farmers in a timely manner. Rural education is increasingly becoming important means of disseminate these information, however

\footnotetext{
${ }^{1}$ Kehinde Adesina Thomas

Department of Agricultural Extension and Rural Development, University Of Ibadan

kehindeadesina@yahoo.com

${ }^{2}$ yobami Abiola Laseinde

Department of Agricultural Extension and Rural Development, University Of Ibadan

kehindeadesina@yahoo.com
} 
many rural schools still operate tenuously, some relying on untrained or volunteer teachers necessarily disconnected from pedagogical training or dominance of the subject matter.

Currently in Nigeria, agricultural information comes mainly from research institutions, which generates new technologies to farmers. It thus follows that the agricultural research information service center is the custodian of several information resources including CD-Rom databases (which could be bibliographic, research, factual), multimedia knowledge bases and in house publication. Other sources may include agricultural information providers such international organizations and local non-governmental organizations and community based organization. The main modes of delivery are farmers' magazines, newspaper, posters, handbooks, radio, television, films and videos. However, there are ample rooms for testing other forms of information dissemination, such as the mobile telecommunication system (Omotayo, 2005).

Social media use for disseminating agricultural information has the potential to bridge the gap created by the short fall in the farmers' extension ratio. The ratio of extension agents to farm families as recommended by Food and Agricultural Oraganisation is put at 1:250; this is against 1: 4,882 with 415,030 farm families in Oyo state (FAO, 2012). The use of social media is becoming increasingly necessary among all professionals of the world. The information that is transfer on the social media cannot be compared to any other means of information dissemination in the world because it gives direct access to information source and how to go about the use of the information gathered. This is believed to have the potential to change the face of agriculture in Nigeria and improve or increase the channel of gathering information among farmers because the ratio of agricultural extension officers is very low compare to the number of farmers that exist in the country (FMARD, 2011).

The field of agricultural extension specializes in the dissemination of information to the farmers and rural dwellers to improve their standard of living in all aspect of life. Social media could provide a platform for an interaction mediated by electronic communication between the farmers or extension officers. According to Ogungbameru (2004), when there is difference or gap between actual performance and what is needed or expected, productivity suffers. Training can reduce it if it does not completely eliminate this gap. The training is to improve the means of disseminating information through the use of social media. The rate at which technology is increasing is overwhelming and social media as a part of technology improvement is growing day by day. Integrating social media into extension work for disseminating agricultural information to farmers will elicit easy access to innovations and invariably improve agricultural production. However, the use of social media is not yet maximized by professionals in Nigeria and as such makes it difficult for farmers to get necessary information to solve their problems.

In the recent time, extension service, service providers and extension clients are experimenting with new digital opportunities that can be effectively used to exchange process, manage and communicate information to help rural farmers to effectively utilize any agricultural information received (Sanusi, Petu-Ibikunle and Mohelia, 2010). Therefore, It suggests that competent and welltrained extension agents are needed if adoption of new technologies required to achieve Millennium Development Goals (MGDs) hope to be achieved in 2015. Social media will provide quick and easy way to build relationships and interact with people in agriculture. Social media creates a much broader agriculture community, so obstacles like physical distance and isolation are issues of the past (MSU, 2012).

One of the major roles of social media in extension is its ability to facilitate effective linkage between extension workers and farmers and also between farmers and research result. IDU (2006), a study conducted on cyber Extension (University Based Extension Based Project for Agricultural Research) found that the web could be effectively used to facilitate extension work, appropriate forum for educational outreach and cost-effective means to reach extension agents, educators and opinion leaders who will transfer the knowledge gained to their clientele. It is against this backdrop that the study was carried out to assess the training needs of extension agents on the use of social media for agricultural information dissemination in Oyo State, Nigeria. The specific objectives are to: 
determine the perception of extension agents on the use of social media for agricultural information dissemination.

1. determine the awareness of the extension agents on the use of social media for agricultural information dissemination.

2. investigate the knowledge of extension agents on the use of social media for agricultural information dissemination.

3. ascertain the constraints in the use of social media by extension agent.

\section{Hypotheses}

a) There is no significant relationship between types of social media used and training needs on social media.

b) There is no significant relationship between perception of social media and training needs on social media.

c) There is no significant relationship between knowledge of social media and training needs on social media.

\section{Methodology}

\subsection{Study Area}

The study was carried out in Oyo state, Nigeria. Oyo State is an inland state in south-western Nigeria, with its capital at Ibadan. It is bounded in the north by Kwara State, in the east by Osun State, in the south by Ogun State and in the west partly by Ogun State and partly by the Republic of Benin. Oyo state is situated in Latitude $7^{0} 241 \mathrm{~N}$ and Longitude $3^{0} 54 \mathrm{E}$ as well as altitude $234 \mathrm{~m}$ above sea level. Oyo state was created in February, 1976 and covers a total of $28,454 \mathrm{SqKm}$ of land mass. Oyo state has a population of about 5, 591, 589 people with 33 local government areas. The Climate is equatorial, notably with dry and wet seasons with relatively high humidity. The dry season lasts from November to March while the wet season starts from April and ends in October. Average daily temperature ranges between $25{ }^{\circ} \mathrm{C}\left(77.0^{\circ} \mathrm{F}\right)$ and $35^{\circ} \mathrm{C}\left(95.0^{\circ} \mathrm{F}\right)$, almost throughout the year (wikipedia, 2013).

The population of the study constituted all the agricultural extension agents that work under Agricultural Development Programme (ADP) in Oyo state.

Sampling Procedure and Sample size: Oyo state has four Agricultural Development Programme (ADP) zones which include Ibadan/Ibarapa, Saki, Oyo and Ogbomosho zones. Ibadan|Ibarapa has 35, Saki 22, Oyo 19 and Ogbomosho 14 extension agents to give a total of 90 respondents. All the 90 extension agents in the state were sampled for the study.

\subsection{Measurement of variables}

\section{Independent Variables}

\section{The use of Social Media}

Respondents were provided with list of the following social media: Facebook, Twitter, MySpace, BBM, YouTube, Yahoo Messenger, MSN, goggle talk, logbook, LinkedIn. They were asked to respond to questions related to access, frequency of use and the purpose for which they are used. The mean score was determined to ascertain respondents' access, frequency of use and the purpose for which social media were used for various purposes. This was measured at interval level of measurement

\section{Perception on the use of social media}

Respondents were asked to react to 21 perception 5 likert scale statements to ascertain their perception on the training needs on the use of social media for agricultural information dissemination. All positive statements were scored 5, 4,3,2,1, while negative statements were score in 
reverse other. The perception value above the mean was considered favorable and below mean unfavorable. This was measured at nominal level of measurement.

\section{Knowledge on the use of Social media}

Respondents were presented with 16 social knowledge questions. Correct response was score 1 and incorrect response 0 . The maximum score was 16 , while the minimum score was 0 . The scores were standardised using the mean to categorise respondents' knowledge on the use of social media into high and low. This was measured at nominal level of measurement.

\section{Dependent Variables}

The dependent variable for this study is the training need on the use of social media. A two point rating scale was used to measure the training needs. The scale was coded needed (1) and not needed (0). A mean value was used to represent the responses into needed and not needed. A training need that was needed has a score equal or above mean and while lower than mean was not needed. This was measured at interval level of measurement.

\section{Results and Discussion}

Structured questionnaire was administered to all the 90 extension agents sampled by trained enumerators. However, $91.1 \%$ return rate was obtained that represented 82 respondents analysed and discussed in this section. Data were analysed with Statistical Package for Social Sciences (SPSS) software to obtain the Pearson Product Moment Correlation (r) and Chi Square $\left(\chi^{2)}\right.$ values.

\section{Distribution of Respondents according to their personal Characteristics}

Table 1 shows that the mean age of extension agents in Oyo State was 38 years, as the majority (84.1\%) of them were between 28 and 49 years old. Only $4.9 \%$ and $11.0 \%$ of them were younger than 28 years and older than 49 years, respectively. This result is consistent with Akinbile (2007) who found that population between 21 and 40 years of age constitute the active work force. It implies that even distribution of age among the extension agents will assure continuity in the extension processes and knowledge exchange among the extension agents required for increase productivities. Majority $(89.0 \%)$ of the extension agents were male while only $11.0 \%$ of them were females. This indicates a serious gender imbalance in the Agricultural Development Projects of the State. In Akinsorotan and Oladele (2009) Agricultural Development Project extension officer are mainly male officers and this is not good for gender equality in extension services. The result further revealed that most of the respondents were married $(91.5 \%)$ while only $8.5 \%$ were single. Nearly all $(98.8 \%)$ had one form of tertiary education or the other. This result indicates that extension service delivery among the literate minds. This will provide a solid platform to inculcate social media training for dissemination agricultural information required to drive the development of agricultural transformation agenda. (FMRAD, 2011) asserted that education is required as a basic prerequisite to sharpen extension agents' knowledge, skills and practices for effective delivery if food security will be achieved in Nigeria.

Table 1 further show that the mean income per annum of the extension agents was $\$ 2,016$. The majority (78.0\%) of them earn between $\$ 884$ and $\$ 3,149$ per annum. The income distribution of the agents reveals that the agents were not well paid in the study area. Consequently, their financial status will affect their purchasing power of ICTs needed for social media. FAO (2012) opined all agricultural extension agents should be well remunerated as an incentive to ensure proper and adequate agricultural information delivery. The mean year of experience of the extension agents was 7 years. The majority (84.1\%) of them had between 2 and 13 years of experience. It implies that majority of the extension agents are still learning on the job and adapting to new technologies might not be difficult, this consistent with Jibowo (2005). On the type of extension services used by the respondents, majority (62.2\%) operates the $\mathrm{T} \& \mathrm{~V}$ service delivery system, while $24.4 \%$ of them operate the general extension service system. Only $3.6 \%$ specialised in crop and fishery extension, while $6.0 \%$ were specialised in women extension service delivery system. It implies that there is a dearth of specialised extension service delivery system in the state and as such makes dissemination of viable information through social media somewhat difficult. This is against Sokoya, Onifade and 
Alabi (2012) who found that extension services delivery is developing fast due to the introduction of information communication technology.

Table 1. Distribution of the extension agents according to their personal characteristic $\mathrm{N}=82$

\begin{tabular}{|c|c|c|}
\hline Variables & Frequency & Percentage \\
\hline \multicolumn{3}{|c|}{ Age category (in years) } \\
\hline$<28$ & 4 & 4.9 \\
\hline $28-49$ & 69 & 84.1 \\
\hline$>49$ & 9 & 11.0 \\
\hline \multicolumn{3}{|l|}{ Mean $=38$} \\
\hline \multicolumn{3}{|l|}{ Sex } \\
\hline Male & 73 & 89.0 \\
\hline Female & 9 & 11.0 \\
\hline \multicolumn{3}{|l|}{ Marital status } \\
\hline Single & 7 & 8.5 \\
\hline Married & 75 & 91.5 \\
\hline \multicolumn{3}{|c|}{ Educational level } \\
\hline Secondary & 1 & 1.2 \\
\hline Tertiary & 81 & 98.8 \\
\hline \multicolumn{3}{|c|}{ Income per annum (\$) } \\
\hline$<884$ & 17 & 20.7 \\
\hline $884-3,149$ & 64 & 78.0 \\
\hline$>3,149$ & 1 & 1.2 \\
\hline \multicolumn{3}{|l|}{ Mean $=2,016$} \\
\hline \multicolumn{3}{|l|}{ Religion } \\
\hline Christianity & 65 & 79.3 \\
\hline Islam & 17 & 20.7 \\
\hline \multicolumn{3}{|c|}{ Years of experience } \\
\hline$<2$ & 3 & 3.7 \\
\hline $2-13$ & 69 & 84.1 \\
\hline$>13$ & 10 & 12.2 \\
\hline \multicolumn{3}{|c|}{ Mean $=7$} \\
\hline \multicolumn{3}{|c|}{ Type of extension service } \\
\hline General & 20 & 24.4 \\
\hline Crop & 3 & 3.6 \\
\hline Fishery & 3 & 3.6 \\
\hline Women & 5 & 6.0 \\
\hline $\mathrm{T}$ and $\mathrm{V}$ & 51 & 62.2 \\
\hline
\end{tabular}

\section{Distribution of Respondents according to the Type of ICTs use for Social Media}

Table 2 shows that all (100.0\%) of the extension agents were using mobile phones for extension services particularly through text messages which a major component of the growth enhancement scheme of the agricultural transformation agenda of the Federal Government of Nigeria. Very few were using laptops (26.8\%) and desktop computers (20.7\%) for extension work. However, none of the extension agents were using the latest multifunctional ICTs that is iPads and tablets which is an indication that the use of ICTs was still low among the agents. Tesfaye (2010) opined that multifunctional ICTs like iPads and tablets offer quicker access to social media as it can be moved around in the farms and rural environment. 
Table 2. Distribution of ICTs Use by Extension Agents

\begin{tabular}{lll}
\hline ICTs & Frequency & Percentage \\
\hline Mobile phone & 82 & 100.0 \\
Laptops & 22 & 26.8 \\
Desktop computer & 17 & 20.7 \\
Ipads & 0 & 0.0 \\
Tablets & 0 & 0.0 \\
\hline
\end{tabular}

\section{Distribution of Respondents according to Social media use for Information}

Table 3 shows that Facebook was the mostly (47.6\%) used social media among the agents, followed by Yahoo Messenger (22.0\%). This medium if well harnessed the gap between researchers and farmers can be bridged. This is premised on the fact that social media enables blogging, tagging, discussion and networking. Social networking sites are becoming the mainstream cultural phenomenon and Agricultural Researchers (ARS) have found tremendous role social media can play in establishing connections, facilitating dissemination of agricultural research findings and exchange of information as an important ingredient for increasing agricultural production (Boyd and Ellison, 2007).

Table 3. Distribution of Social Media Use by Agricultural Extension Agents $\quad \mathrm{N}=82$

\begin{tabular}{lll}
\hline Variables & Frequency & Percentage \\
\hline Twitter & 7 & 8.5 \\
MySpace & 8 & 9.8 \\
Facebook & 39 & 47.6 \\
YouTube & 9 & 11.0 \\
BBM & 7 & 8.5 \\
Google talk & 10 & 12.2 \\
Flickr & 2 & 2.4 \\
LinkedIn & 3 & 3.7 \\
Yahoo messenger & 18 & 22.0 \\
MSN & 10 & 12.2 \\
Logbook & 2 & 2.4 \\
Pheed & 0 & 0.0 \\
\hline
\end{tabular}

Respondents' Perception of social media for information Dissemination

Table $4 \mathrm{a}$ and $4 \mathrm{~b}$ show the distribution of respondents according to their perception of social media for agricultural information Dissemination. Extension agents perceived the use of social media to be effectively save time and energy (mean=3.6), they also felt that misuse of social media can negatively affect the extension agent in charge of account (mean=2.9). Extension agents expressed the fact that Social media can be used in other aspect side from extension service delivery $($ mean $=2.4)$. The Tables further show that more $(54.9 \%)$ of the extension agents had a favourable perception of social media while $45.1 \%$ were unfavourably disposed to social media use. The implication of this is that the extension agents' perception of social media was favourable and if the advantages can be maximised for disseminating agricultural information, farmers will have access to results of researchers needed to boost production. This finding is consistent with Sokoya et al (2012) who affirmed that disposition to the use of social media can affect the use for whatever purpose it is intended. 
Table 4a. Distribution of Extension Agents' Perception 0f Social Media $\quad \mathrm{N}=82$

S/n Statement Strongly Agree Undecided Disagree agree

Strongly Mean disagree

\begin{tabular}{|c|c|c|c|c|c|c|c|}
\hline 1 & $\begin{array}{l}\text { Social media aids or encourage } \\
\text { information dissemination }\end{array}$ & $45(54.9)$ & $\begin{array}{l}29 \\
(35.4)\end{array}$ & - & $8(9.8)$ & - & 1.7 \\
\hline 2 & $\begin{array}{l}\text { Age is not a barrier in the use of social } \\
\text { media }\end{array}$ & $19(23.2)$ & $\begin{array}{l}43 \\
(52.4)\end{array}$ & $10(12.2)$ & $10(12.2)$ & - & 2.1 \\
\hline 3 & $\begin{array}{l}\text { Social media can be use in extension } \\
\text { delivery services }\end{array}$ & $37(45.1)$ & $\begin{array}{l}32 \\
(39.0)\end{array}$ & $4(4.9)$ & $4(4.9)$ & - & 1.6 \\
\hline 4 & $\begin{array}{l}\text { The use of social media may not } \\
\text { effectively save time and energy }\end{array}$ & $8(9.8)$ & $\begin{array}{l}12 \\
(14.6)\end{array}$ & $4(4.9)$ & $24(29.3)$ & $31(37.8)$ & 3.6 \\
\hline 5 & $\begin{array}{l}\text { Social media can be used in other aspect } \\
\text { of life than in extension delivery service }\end{array}$ & $25(30.5)$ & $\begin{array}{l}22 \\
(26.8)\end{array}$ & 12 (14.6) & $20(24.4)$ & $3(3.7)$ & 2.4 \\
\hline 6 & $\begin{array}{l}\text { For new users, social media might } \\
\text { require the technical know-how to } \\
\text { operate it }\end{array}$ & $19(23.2)$ & $\begin{array}{l}58 \\
(70.7)\end{array}$ & $5(6.1)$ & - & - & 1.8 \\
\hline 7 & $\begin{array}{l}\text { Social media encourage a continuity in } \\
\text { inter personal relationship which can } \\
\text { help to maintain a cordial extension } \\
\text { agent to farmer relationship }\end{array}$ & $48(58.5)$ & $\begin{array}{l}31 \\
(37.8)\end{array}$ & $3(3.7)$ & - & - & 1.5 \\
\hline 8 & $\begin{array}{l}\text { Social media has more advantages to } \\
\text { disadvantages }\end{array}$ & $26(31.7)$ & $\begin{array}{l}47 \\
(57.3)\end{array}$ & $6(7.3)$ & $3(3.7)$ & - & 1.8 \\
\hline 9 & $\begin{array}{l}\text { Social media is not a good platform for } \\
\text { confidentiality }\end{array}$ & $17(20.7)$ & $\begin{array}{l}38 \\
(46.3)\end{array}$ & $9(11.0)$ & $17(20.7)$ & $1(1.2)$ & 2.4 \\
\hline 10 & $\begin{array}{l}\text { Social media training will encourage the } \\
\text { highest level of extension } \\
\text { professionalism }\end{array}$ & $45(54.9)$ & $\begin{array}{l}29 \\
(35.4)\end{array}$ & $6(7.3)$ & $2(2.4)$ & - & 1.6 \\
\hline 11 & $\begin{array}{l}\text { Social media encourage important } \\
\text { dialogue }\end{array}$ & $41(50.0)$ & $\begin{array}{l}33 \\
(40.2)\end{array}$ & $8(9.8)$ & - & - & 1.6 \\
\hline 12 & $\begin{array}{l}\text { Social media promotes better and fast } \\
\text { agriculture solution }\end{array}$ & $46(56.1)$ & $\begin{array}{l}30 \\
(36.6)\end{array}$ & $5(6.1)$ & $1(1.2)$ & - & 1.5 \\
\hline 13 & $\begin{array}{l}\text { Extension agents can pay more attention } \\
\text { to details through social media }\end{array}$ & $33(40.2)$ & $\begin{array}{l}26 \\
(31.7)\end{array}$ & $2(2.4)$ & $8(9.8)$ & $13(15.9)$ & 2.3 \\
\hline 14 & $\begin{array}{l}\text { Social media encourage easy access to } \\
\text { information for extension agents }\end{array}$ & $38(46.3)$ & $\begin{array}{l}33 \\
(40.2)\end{array}$ & $5(6.10$ & $3(3.7)$ & - & 1.6 \\
\hline 15 & $\begin{array}{l}\text { Social media is a good way to enlighten } \\
\text { the farmers on issues relating to whatever } \\
\text { problem they are facing }\end{array}$ & $38(46.3)$ & $\begin{array}{l}30 \\
(36.6)\end{array}$ & $9(11.0)$ & $5(6.1)$ & - & 1.8 \\
\hline 16 & $\begin{array}{l}\text { Social media is the best way to improve } \\
\text { extension delivery service in Nigeria }\end{array}$ & $41(50.0)$ & $\begin{array}{l}37 \\
(45.1)\end{array}$ & $3(3.7)$ & $1(1.2)$ & - & 1.6 \\
\hline 17 & $\begin{array}{l}\text { Social media aids the coming together of } \\
\text { people in their groups }\end{array}$ & $36(43.9)$ & $\begin{array}{l}34 \\
(41.5)\end{array}$ & $6(7.3)$ & $6(7.3)$ & - & 1.8 \\
\hline 18 & $\begin{array}{l}\text { Social can be used to easily track farmers } \\
\text { inputs and outputs }\end{array}$ & $25(30.5)$ & $\begin{array}{l}40 \\
(48.8)\end{array}$ & $6(7.3)$ & $7(8.5)$ & $4(4.9)$ & 2.1 \\
\hline 19 & $\begin{array}{l}\text { Social media help in achieving } \\
\text { transparency in extension services }\end{array}$ & 36 (43.9) & $\begin{array}{l}30 \\
(36.6)\end{array}$ & $4(4.9)$ & 12 (14.6) & - & 1.9 \\
\hline 20 & $\begin{array}{l}\text { Social media bring about collaboration } \\
\text { between extension agents across the } \\
\text { globe }\end{array}$ & $41(50.0)$ & $\begin{array}{l}32 \\
(39.0)\end{array}$ & $7(8.5)$ & $2(2.4)$ & - & 1.6 \\
\hline 21 & $\begin{array}{l}\text { Social media misuse can affect the } \\
\text { extension agent in charge of the account }\end{array}$ & $10(12.2)$ & $\begin{array}{l}27 \\
(32.9)\end{array}$ & $19(23.2)$ & $13(15.9)$ & 13 (15.9) & 2.9 \\
\hline 22 & $\begin{array}{l}\text { There is need for training on the use of } \\
\text { social media for extension agents }\end{array}$ & $41(50.0)$ & $\begin{array}{l}31 \\
(37.8)\end{array}$ & $7(8.5)$ & - & - & 1.5 \\
\hline
\end{tabular}


Table 4b. Extension Agents' Level of Perception of Social Media

$\mathrm{N}=82$

\begin{tabular}{lll}
\hline Variable & Frequency & Percentage \\
\hline Unfavourable & 37 & 45.1 \\
Favourable & 45 & 54.9 \\
\hline
\end{tabular}

\section{Distribution of Respondents according to their Knowledge of social media}

Knowledge test results on Table 5 revealed that many respondents already had basic knowledge of social media. About $95.1 \%$ of the extension agents knew about social media and $92.7 \%$ knew that it can be used to share innovation. Also, 91.5\% knew that it can be used to send information to many people in different places within a short period of time and can be used to store contact details. Okwu and Daudu (2011) observed that Nigeria has an elaborate agricultural research and extension system but the result of these researches are not fully made available to the end users; hence, the researchers, extension workers, farmers, which means that end users are not sufficiently exposed to new knowledge. It is imperative there that effort should be made by relevant government and nongovernment agencies to establish connections among stakeholders for proper dissemination of current and relevant information/knowledge for sustainable agricultural production.

Table 5. Distribution of Extension Agents' Knowledge of Social Media

\begin{tabular}{llll} 
& \multicolumn{1}{c}{ Yes } & N=82 \\
\hline S/n & Statement & Frequency & Percentage \\
1 & Have you heard about social media e.g Facebook, twitter, YouTube, & 78 & 95.1 \\
& 2go, MSN, Pheed etc & 69 & 84.1 \\
2 & Do you use social media for personal communication & 62 & 75.6 \\
3 & You can upload video, picture, message via social media & 65 & 79.3 \\
4 & You can communicate with your farmers through social media & 75 & 91.5 \\
5 & You can send information to many in different places within a short & & 59.8 \\
& period via social media & 49 & 51.2 \\
6 & You cannot create personal accounts on social media & 42 & 84.1 \\
7 & It is possible to see your farmers while attending to them via social & & 82.9 \\
& media & 69 & 67.1 \\
8 & You can attach documents to be sent through social media & 55 & 92.7 \\
9 & You can have personal information or notes on social media & 76 & 91.5 \\
10 & You can have conference talk through social media & 75 & 79.3 \\
11 & You can share new innovation through social media & & \\
12 & You can have most of your contact details on social media e.g phone & 75 & \\
& number, email etc & 65 & \\
13 & Most of your social media account can be linked to each other & & \\
\hline
\end{tabular}

\section{Distribution of Extension Agents' Awareness of Social Media}

Table 6 reveals that Facebook is the social media that was the most popular (97.6\%) and followed by Yahoo Messenger (69.5\%). Other social media that they were familiar with include Blackberry Messenger (58.5\%), Google Plus (53.6\%), Google Talk (52.4\%), Youtube (46.3\%) and Twitter (42.7). All the respondents maintain at least one account with the social networking sites, but Facebook was the most popular social media used by agricultural extension officers in Nigeria. This support the opinion of Boyd and Ellision (2010) that Facebook is the most used social media in Nigeria. 


\begin{tabular}{|c|c|c|c|}
\hline $\mathbf{s} / \mathbf{n}$ & Social media & Yes & \\
\hline & & Frequency & Percentage \\
\hline 1 & Facebook & 80 & 97.6 \\
\hline 2 & Twitter & 35 & 42.7 \\
\hline 3 & YouTube & 38 & 46.3 \\
\hline 4 & Blogs & 16 & 19.5 \\
\hline 5 & MSN & 25 & 30.5 \\
\hline 6 & Google talk & 43 & 52.4 \\
\hline 7 & Yahoo messenger & 57 & 69.5 \\
\hline 8 & Google plus & 44 & 53.6 \\
\hline 9 & $2 \mathrm{go}$ & 51 & 62.2 \\
\hline 10 & $\mathrm{BBM}$ & 48 & 58.5 \\
\hline 11 & Pheed & 16 & 19.5 \\
\hline 12 & Logbook & 17 & 20.7 \\
\hline 13 & MySpace & 23 & 28.0 \\
\hline 14 & LinkedIn & 17 & 20.7 \\
\hline 15 & Flickr & 15 & 18.3 \\
\hline 16 & $\mathrm{Hi} 5$ & 15 & 18.3 \\
\hline 17 & Friend feed & 15 & 18.3 \\
\hline
\end{tabular}

\section{Training need}

Table 8 reveals that the top needed areas of training in the use of Facebook among the agents were 'tagging contact to a picture or video (70.7\%), 'placing an advertisement (70.7\%)', 'creating a group $(68.3 \%)$ ' and 'uploading pictures and videos (64.6\%)'. The top needed areas of training in the use of Twitter were 'opening an account (78.0\%)', 'posting a link $(76.8 \%)$ ' and 'making a tweet one's favourite (76.8\%)'. In addition, the top needed areas of training in the use of YouTube were 'placing an advertisement (78.0\%)', 'posting a video message (76.8\%)' and 'viewing a video (76.8\%)'. The top needed areas of training in the use of Blog were 'creating an account (76.8\%)', 'posting messages and information (76.8\%)' and 'maintaining an account (76.8\%)'. This result shows that the extension agents require basic skills in the use of all the social media.

Table 8. Distribution of Extension Agents' Training Need on the Use of Social Media N=82

\begin{tabular}{llll}
\hline S/n & Variable & Needed & \\
\hline & & Frequency & Percentage \\
A & Area of training Facebook & & \\
1 & Opening Facebook account & 48 & 58.5 \\
2 & Uploading pictures and videos & 53 & 64.6 \\
3 & Posting message & 40 & 48.8 \\
4 & Share Information & 41 & 50.0 \\
5 & Create your group & 56 & 68.3 \\
6 & Send and receive messages & 39 & 47.6 \\
7 & Place an advertisements & 58 & 70.7 \\
8 & Search for new friends & 45 & 54.9 \\
9 & Add new friends & 46 & 56.1 \\
10 & Tag contact to a picture or video & 58 & 70.7 \\
B & Area of training on Twitter & & \\
1 & Open an account & 64 & 78.0 \\
2 & Post tweet & 55 & 67.1 \\
3 & Post link & 63 & 76.8 \\
4 & Follow a friend & 57 & 69.5 \\
5 & Unfollow a friend & 55 & 67.1 \\
6 & Search for new friends & 54 & 65.9 \\
7 & Make a tweet your favorite & 63 & 76.8 \\
\hline
\end{tabular}




\begin{tabular}{llll}
\hline S/n & Variable & Needed & \\
\hline 8 & Send and read direct messages (DM) & 54 & 65.9 \\
C & Area of training on YouTube & & \\
1 & Open an account & 60 & 73.2 \\
2 & Receive video message & 60 & 73.2 \\
3 & Post video message & 63 & 76.8 \\
4 & Placing advertisement & 64 & 78.0 \\
5 & Searching for videos & 61 & 74.4 \\
6 & downloading video & 61 & 74.4 \\
7 & How to view video & 63 & 76.8 \\
D & Area of Training on Blog & & \\
1 & Create an account & 63 & 76.8 \\
2 & Post messages or information & 63 & 76.8 \\
3 & Receive message or information & 62 & 75.6 \\
4 & Create a link to other media & 62 & 75.6 \\
5 & Maintain an account & 63 & 76.8 \\
E & Area of training on 2go & & \\
1 & Registration of an account & 59 & 72.0 \\
2 & Receive and send message & 58 & 70.7 \\
3 & linking it to other social media & 58 & 70.7 \\
4 & Receive messages from other social & 58 & 70.7 \\
& media & & \\
\hline
\end{tabular}

\section{Hypotheses testing}

Result of analysis on Table 9 shows that there were no significant relationship between sex $\left(\chi^{2}=1.347, \mathrm{p}>0.05\right)$, religion $\left(\chi^{2}=1.652, \mathrm{p}>0.05\right)$, type of extension practice $\left(\chi^{2}=8.729, \mathrm{p}=0.05\right)$ and their training need on the use of social media. However, there was a significant relationship between their educational level $\left(\chi^{2}=10.142, p<0.05\right)$, marital status $\left(\chi^{2} 19.632, p<0.05\right)$ and training need on the use of social media. This result implies that the extension agents' training need on the use of social media is irrespective of their sex, religion and type of extension practice, but on their marital status and educational level. The significance of marital status is due to age category. The expected relationship between educational level and training need was upheld; meaning that the more educated an extension agents had less need for training on social media. In a related study, Sokoya et al (2012) affirmed education is imperative to acquiring social media skills.

Table 9. Chi Square relationship between socioeconomic characteristics and training need

\begin{tabular}{llll}
\hline Variable & Chi-square value & df & p-value \\
\hline Sex & 1.347 & 1 & 0.246 \\
Marital status & 19.632 & 2 & $0.000^{*}$ \\
Educational level & 10.142 & 1 & $0.041^{*}$ \\
Religion & 1.652 & 2 & 0.438 \\
Type of extension practice & 8.724 & 5 & 0.121 \\
\hline
\end{tabular}

\section{*significant : $\mathbf{p}<0.05$}

Result of analysis on Table 10 shows that there was significant relationship between social media used $(\mathrm{r}=-0.337, \mathrm{p}<0.05)$ by the extension agents and their training need on the use of social media. This could be due to the similarities in commands of all the social media; an agent that is vast in the use of one is likely to be able to use another well enough, Steinfeld and Lampe (2007) also establish the fact that social media provides a unique environment because of its heavy usage patterns, ability to bridge gaps and similarity among the social media helps in the usage. The Table further revealed that there was a significant relationship between extension agents' perception of social media $(r=0.935$, $\mathrm{p}<0.05)$, knowledge of social media $(\mathrm{r}=-0.875, \mathrm{p}<0.05)$ and their training need on the use of social media. It implies that the extension agents put a lot of value on the potentials of social media and therefore would like to be trained on its use for their professional effectiveness. In a related study, Paul 
(2011) asserted that, afterschool professionals increasingly embrace social media platforms as perception and knowledge increases, but there seems to be a limited understanding of its applicability to the workplace. Thus, the call for training becomes imperative for the extension agents.

Table 10. Pearson Product Moment Correlation (PPMC) Showing Relationship between Social Media Used, Perception, Knowledge and Training Need

\begin{tabular}{lll}
\hline Variables & r-value & p-value \\
\hline Perception of social media & 0.935 & $0.028^{*}$ \\
Knowledge of social media & -0.875 & $0.033^{*}$ \\
Social media used & -0.337 & $0.002^{*}$
\end{tabular}

\section{*significant $\mathbf{:} \mathbf{p}<0.05$}

\section{Conclusion and Recommendations}

The weak linkage between researchers, extension agents and farmers explains the failure in application of research findings to improve rural poor farmers. A critical and effective training platform for agricultural extension agents will foster meaningful participation to harness social media skills. Deliberate capacity building programme as an integral part of all ICT projects will also guarantee food security and human resource development through knowledge building and information sharing. Based on the foregoing, the following recommendations were made:

- Agricultural extension training should encourage e-learning programmes using various social media platforms.

- Relevant stakeholders in agricultural extension delivery should facilitate an extension system that is ICTs driven.

- Nigerian agricultural technology transfer policy should emphasize the use of social media for transfer of technical information to farmers.

\section{References}

Akinbile, L.A (2007). Social Impact of limestone Exploitation in Yewa North Local Government Area of Ogun State, Nigeria.Pakistan Journal of Social Science 1:107 111, Maxwell

Journal

Akinsorotan, A.O and Oladele, O.I (2007). Organizational Values Perceived as evident among Extension Agents of Agricultural Development Program in Nigeria. Journal of Agricultural Tropical, Subtropics Vol 42, (3).

Boyd, D.M. and N.B. Ellision. (2007). "Social Network Sites: Definition, History, and Scholarship." J. Comp.Mediated Comm. 13: Article 11 doi:10.1111/j.1083-6101.2007.00393.x

Extension Service of Mississippi State University (MSU, 2012), www.msucares.com/pubs/infosheets retrieved 17 January 2013.

FAO (2012). Urban and peri - Agriculture. Food and Agricultural Organization (FAO) of the United Nations, document pp 19-23. Retrieved 19 January, 2013 from http://faostat.fao.org//default.htm

FMARD (2011): "Agricultural Transformation Agenda" Nigeria: Report on Agricultural Extension Transformation" Federal Ministry of Agriculture and Rural development, Abuja. Research Enugu: New Generation Books.

IICD (International Institute for Communication and Development) (2006): ICTs for Agriculture Livelihoods: Impact and Lessons Learned from IICD Supported Activities. The Hague: IICD.http://www.iicd.org/files/IICDagri-impact-2006.pdf, accessed July 2014.

Jibowo, A.A. (2005): History of Agricultural Extension in Nigeria. In: Adedoyin, S.F. (ed).Agricultural Extension in Nigeria. Ilorin: Agricultural Extension Society of Nigeria, pp.1-15

Ogunbameru, B.O. (2004). Training Development in: Akinsorotan "Element of Agricultural Extension Administration" Personal Management. Bounty Press, Ibadan, p.65. 
Okwu, O.J. and Daudu, S. (2011) "Extension Communication Channels' Usage and Preference by Farmers in Benue State, Nigeria "Journal of Agricultural extension and Rural Development 3(5) 88-94

Omotayo, A.M. (2005): Information Communication Technology and Agricultural Extension: Emergency Issues in Transferring Agricultural Technology in Developing Countries. In Adedoyin, S.F. (ed) Agricultural Extension in Nigeria, ARTMI. Ilorin

Paul Young (2011). National Afterschool Association; Social Media Usage Practices Among Afterschool Professionals. Social Media Survey via Survey Monkey, April-May, 2012

Sanusi, M.A, Petu-Ibikunle, A.M and C.M Mohelia (2010): The influence of ICT on the dissemination of Agricultural Information among urban farmers in Northern Guinea Savannah Zone of Nigeria. African Scientist 11(2) pg 135-140

Sokoya, A.A, Onifade, F.N and Alabi, A.O. (2012) Establishing connection and Networking; The Role of Social Media in Agricultural Research in Nigeria. World Library and Information Congress. http://conference.ifla.org/ifla78 Retrieve 2nd May, 2013

Steinfeld, R and Lampe,C. (2007). "Trust and privacy concern within social networking sites: A comparison of Facebook and MySpace”. In Proceedings of AMCIS 2007, Keystone, Colarado,USA, 2007 http://csis.pace.edu/ dwyer/research/ SteinfeldLampeIS2007.pdf. Retrieved February 18, 2014

Tesfaye Nekatibebe (2010). Evaluating the Impact of Social Media on Traditional Marketing, Helsinki Metropolia University of Applied Sciences BBA Business Administration International Business and Logistics Bachelor's Thesis.

Wikipedia (2013): http://en.wikipedia.org/wiki/Oyo State 